\title{
Rapid Blood Transfusion: The Importance of Hemodilution and Needleless Connectors
}

\author{
Mark A. Burbridge ${ }^{1}$, Anil K. Panigrahi ${ }^{2}$, Sarah A. Stone ${ }^{1}$, Richard A. Jaffe ${ }^{1}$, John Brock-Utne ${ }^{1}$ \\ 1. Anesthesiology, Stanford University Medical Center, Stanford, USA 2. Transfusion Medicine; Anesthesiology, \\ Stanford University Medical Center, Stanford, USA
}

Corresponding author: Mark A. Burbridge, markburb@stanford.edu

\begin{abstract}
Introduction: Large-bore cannulas are critical to administering IV fluids and blood products during resuscitation and treatment of hemorrhage. Although catheter flow rates for crystalloid solutions are well defined, rapid administration of blood products is poorly characterized. In this in vitro study, we examined the effects of hemodilution and needleless connectors on red blood cell (RBC) flow rates.
\end{abstract}

Methods: To determine RBC flow rates through large-bore cannulae, a crystalloid solution (Normosol ${ }^{\circledR}$, Hospira, Lake Forest, IL) or RBC units were warmed and delivered under pressure (360 $\mathrm{mmHg}$ ) using a Level $1 \mathrm{H}-1200$ Fast Flow Fluid Warmer (Smiths Medical, St. Paul, MN). Flow rates for crystalloid, packed RBCs and diluted RBCs were determined using a stopwatch. Additionally, the effect of the MaxPlus ${ }^{\circledR}$ clear needleless connector (CareFusion, San Diego, CA) was measured in all three infusion groups.

Results: Flow rates for undiluted RBC units were 53\% slower than crystalloid solution $(220 \mathrm{~mL} / \mathrm{min}$ vs. 463 $\mathrm{mL} / \mathrm{min} ; \mathrm{p}=0.0003$ ), however, when RBC units were diluted to a hematocrit of $\sim 30 \%$ flow rate improved to $369 \mathrm{~mL} / \mathrm{min}(\mathrm{p}=0.005)$. The addition of the MaxPlus ${ }^{\circledR}$ needleless connector reduced flow of crystalloid solution by $47 \%(245 \mathrm{~mL} / \mathrm{min} ; \mathrm{p}=0.0001)$, undiluted RBCs by $64 \%(78 \mathrm{~mL} / \mathrm{min} ; \mathrm{p}=0.01)$, and diluted RBCs by $51 \%$ ( $180 \mathrm{~mL} / \mathrm{min} ; \mathrm{p}=0.00003)$. Compared to undiluted RBC units, hemodilution increased RBC delivery rate through a MaxPlus ${ }^{\circledR}$ connector by $130 \%(\mathrm{p}=0.004)$ and by $68 \%(\mathrm{p}=0.02)$ when the catheter was directly connected to the Level 1 tubing (MaxPlus ${ }^{\circledR}$ excluded).

Conclusion: In settings requiring rapid transfusion of RBC units, needleless connectors should not be used and hemodilution should be considered in order to decrease the time required to deliver an equivalent red cell mass.

Review began 02/26/2021 Review ended 03/16/2021 Published 03/19/2021

\section{๑) Copyright 2021}

Burbridge et al. This is an open access article distributed under the terms of the Creative Commons Attribution License CC-BY 4.0., which permits unrestricted use, distribution, and reproduction in any medium, provided the original author and source are credited.

Categories: Anesthesiology, Emergency Medicine, Trauma

Keywords: massive blood transfusion, packed red blood cell transfusion

\section{Introduction}

Large-bore IV cannulae are critical to administering IV fluids and blood products during resuscitation and treatment of hemorrhage. Although catheter flow rates for rapid transfusion of crystalloid solutions and red blood cell (RBC) transfusions are well defined [1], strategies to safely increase the speed of RBC transfusions are lacking.

A method that may increase the speed of RBC transfusion through rapid transfusion devices is hemodilution. Hemodilution, by decreasing viscosity, will increase flow rates and may decrease the time necessary to transfuse a unit of RBC. However, it is unknown if the effect of the decrease in viscosity would offset the time necessary to deliver the expanded volume of a diluted unit of RBCs.

In addition, incorporating needleless connectors in IV tubing sets has increased in an effort to reduce catheter-related infections and to reduce exposure risk when obtaining blood samples [2-4]. However, these connectors have been shown to substantially reduce the flow of crystalloid solutions through large-bore catheters $[1,5]$.

In this in vitro study, we examined the effect of hemodilution on the speed of transfusion of a unit of RBC with or without the use of needleless connectors using a Level $1{ }^{\circledR}$ rapid infusion system (Smiths Medical, St. Paul, MN).

\section{Materials And Methods}

To determine RBC flow rates through large-bore cannulae, a crystalloid solution (Normosol ${ }^{\circledR}$, Hospira, Lake Forest, IL) or RBC units were delivered into an empty IV plastic infusion bag using a Level $1^{\circledR} \mathrm{H}-1200$ Fast Flow Fluid Warmer and D70 IV fluid administration set placed at a height of six feet (Smiths Medical, St. Paul, MN) connected to a 14 gage x 1.25-inch Introcan Safety IV® ${ }^{\circledR}$ catheter (B Braun Medical, Bethlehem, 
PA). Two Adsol (AS-1) RBC units were combined to create a total volume of $500 \mathrm{~mL}$ with a hematocrit of $61.9 \%$ as confirmed by laboratory measurement. Flow rates for crystalloid, undiluted RBCs, and RBCs diluted with Normosol ${ }^{\circledR}$ to a hematocrit of $29.9 \%$ were measured. One liter bags of Normosol ${ }^{\circledR}$ were used because this size of bag is commonly used in clinical practice when rapid fluid administration is

desired. Additionally, the effect of the MaxPlus ${ }^{\circledR}$ needleless connector (CareFusion, San Diego, CA) was measured in all three conditions. Crystalloid or RBC bags containing measured volumes were pressurized in the Level $1^{\circledR}$ chamber to a starting pressure of approximately $360 \mathrm{mmHg}$ (as measured by an in-line pressure transducer placed at a side port of the Level 1 tubing to eliminate any additional resistance), hung at a height of six feet, heated to 37 degrees Celsius, and the time from the start to the end of flow was measured by a stopwatch. The same bags of undiluted and diluted RBCs were used for uniformity purposes. The same Level 1 tubing set-up was used for the entire experiment, but was thoroughly flushed when diluted and undiluted RBC bags were run. Each flow condition was tested in triplicate. Statistical analysis included ANOVA and a one-tailed t-test. A one-tailed t-test was chosen because it was not necessary to test the possibility that Normosol ${ }^{\circledR}$ would infuse slower than undiluted or diluted RBC units. RBC units were expired and donated by the Stanford University blood bank.

\section{Results}

Mean pressurized flow rates were $463 \mathrm{~mL} / \mathrm{min}$ for crystalloid (standard deviation=20.63 mL/min), 220 $\mathrm{mL} / \mathrm{min}$ for undiluted $\mathrm{RBC}$ units (standard deviation=29.98 mL/min), and $369 \mathrm{~mL} / \mathrm{min}$ for diluted RBC units (standard deviation=10.58 mL/min). Pressurized flow rates for undiluted RBC units were $53 \%$ slower than crystalloid solution ( $220 \mathrm{~mL} / \mathrm{min}$ vs. $463 \mathrm{~mL} / \mathrm{min}$; $\mathrm{p}=0.0003$; Figure 1), however, when $\mathrm{RBC}$ units were diluted to a hematocrit of $\sim 30 \%$ flow rate improved to $369 \mathrm{~mL} / \mathrm{min}$ ( $\mathrm{p}=0.005$; Figure 1 ).

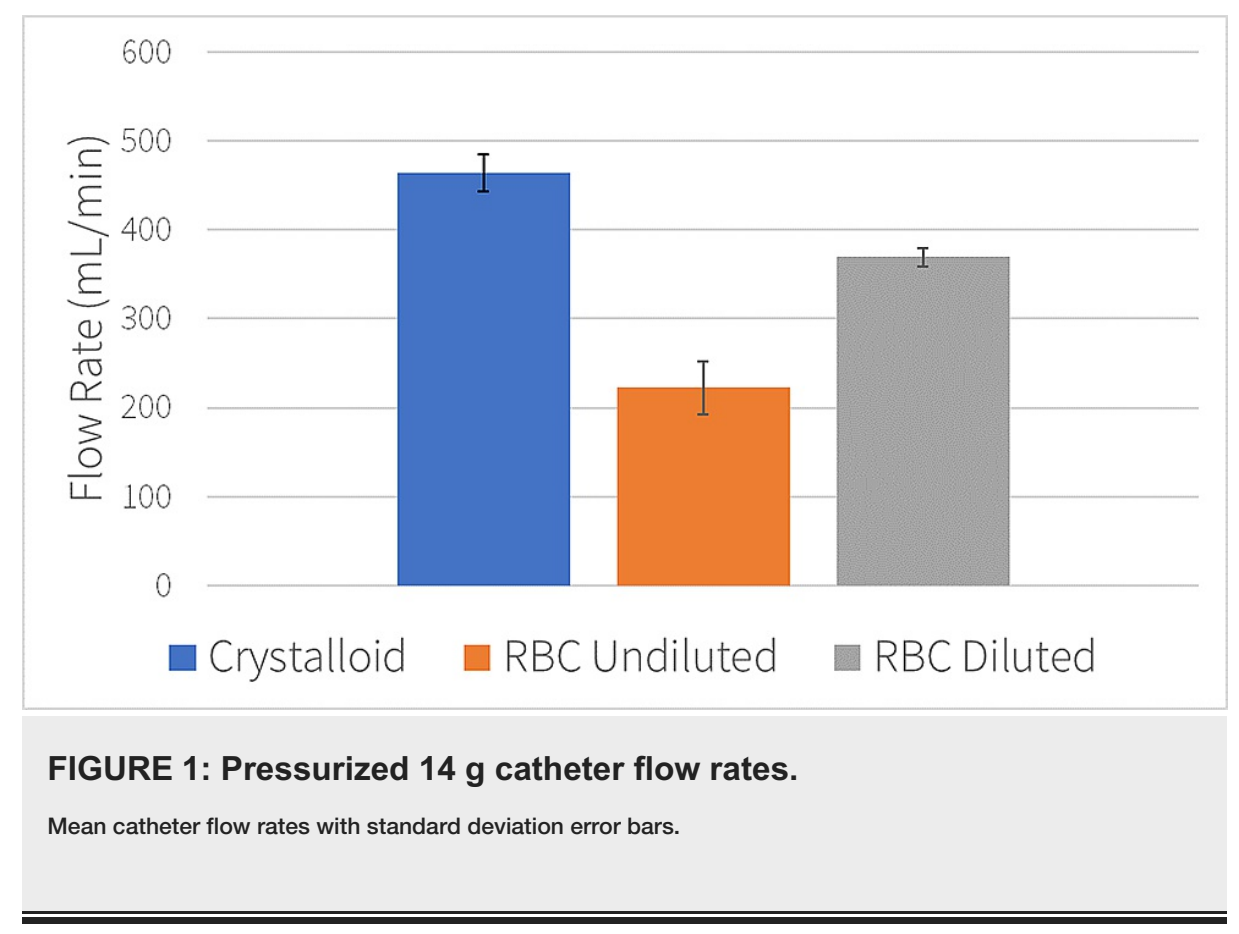

The addition of the MaxPlus ${ }^{\circledR}$ needleless connector resulted in mean flow rates of $245 \mathrm{~mL} / \mathrm{min}$ using crystalloid (standard deviation=14.97 mL/min), $78 \mathrm{~mL} / \mathrm{min}$ using undilted RBC units, and $180 \mathrm{~mL} / \mathrm{min}$ for diluted RBC units (standard deviation=12.42 mL/min). The addition of the MaxPlus ${ }^{\circledR}$ needleless connector reduced pressurized flow of crystalloid solution, undiluted RBC, and diluted RBC by $47 \%(245 \mathrm{~mL} / \mathrm{min}$; $\mathrm{p}=0.0001), 64 \%(78 \mathrm{~mL} / \mathrm{min} ; \mathrm{p}=0.01)$, and 51\% (180 mL/min; $\mathrm{p}=0.00003$, Figures $2-3)$, respectively. 


\section{Cureus}

$$
600
$$

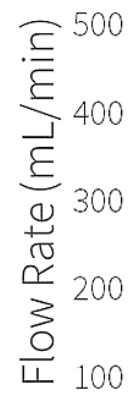

100

0

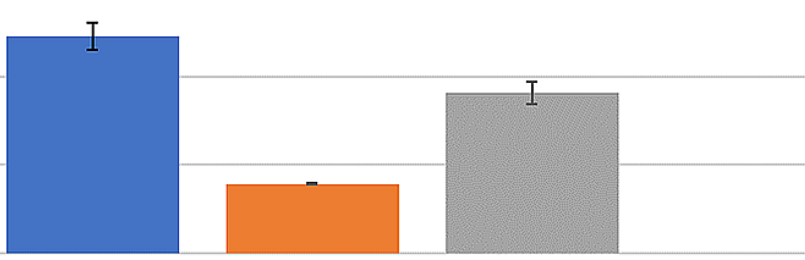

Crystalloid + MaxPlus

RBC Undiluted + MaxPlus

RBC Diluted + MaxPlus

FIGURE 2: Pressurized $14 \mathrm{~g}$ catheter flow rates with needleless

\section{connector.}

Mean catheter flow rates with standard deviation error bars.

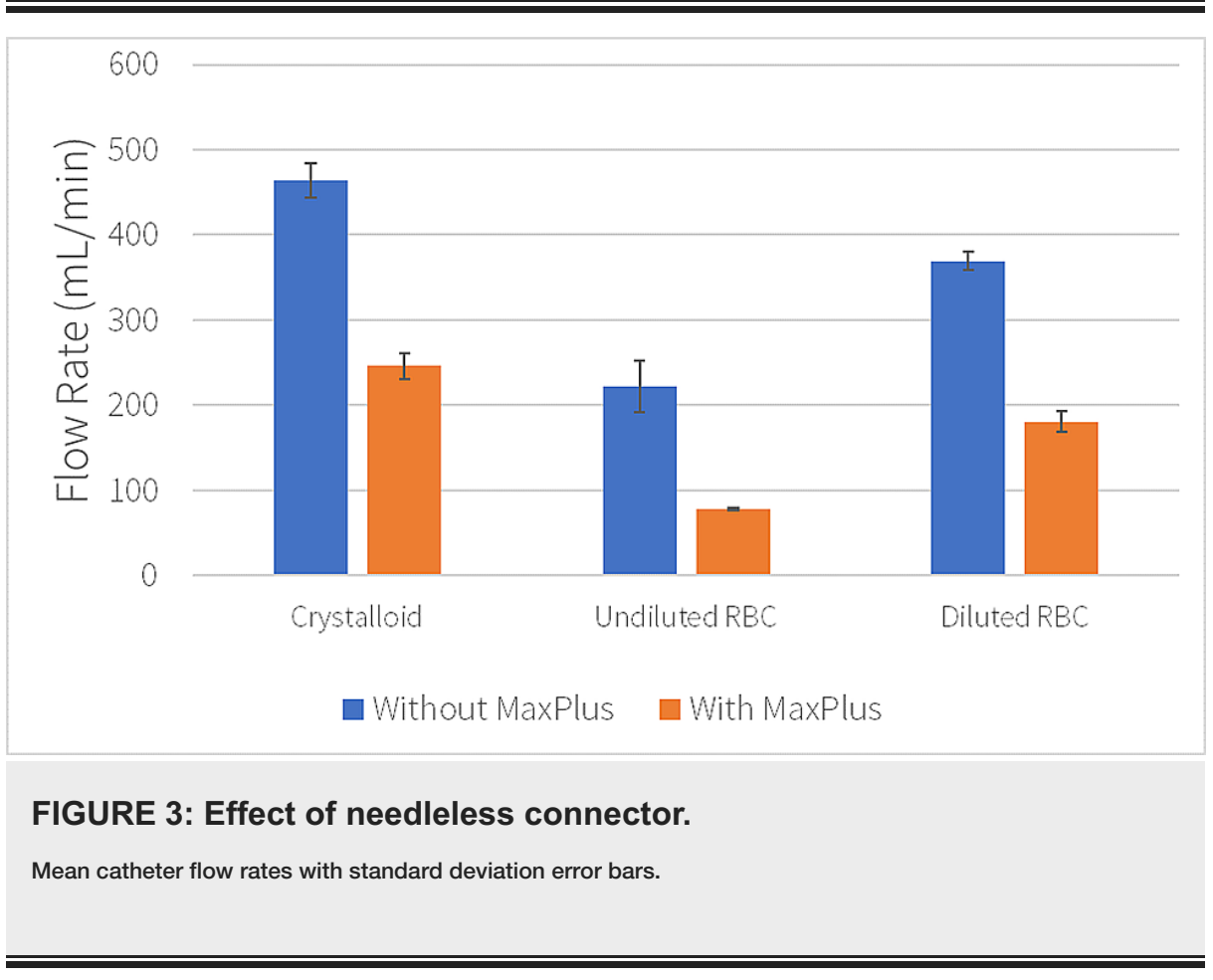

Compared to undiluted RBC units, hemodilution increased RBC flow rates by $130 \%$ ( $\mathrm{p}=0.004)$ through a MaxPlus ${ }^{\circledR}$ connector (Figure 2 ) and up to $68 \%(\mathrm{p}=0.02)$ when the catheter was directly connected to the Level 1 tubing (Figure 1).

Similarly, the time for an infusion of $500 \mathrm{~mL}$ of each solution was affected by the inclusion of a MaxPlus ${ }^{\circledR}$ connector (Figure 4). Mean infusion time for crystalloid and diluted RBC solutions through the needleless connector was approximately double (65-122 s, p=0.001, and 81-166 s, p=0.007, respectively), while the mean time for undiluted RBC was most greatly affected, increasing by $282 \%$ (136-383 s, p=0.002). RBC hemodilution decreased mean infusion time by $40 \%$ when the needleless connector was omitted $(\mathrm{p}=0.04)$. 


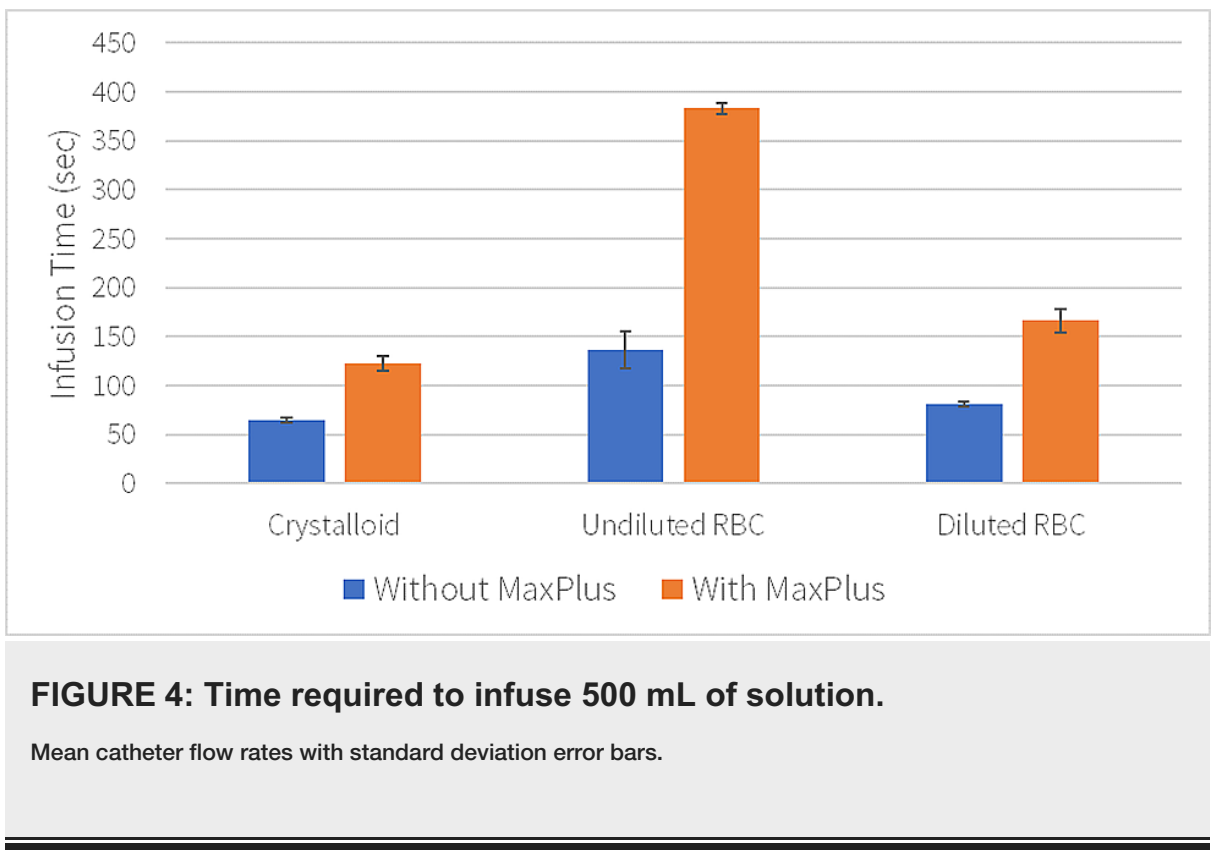

\section{Discussion}

Rapid administration of IV fluids including crystalloid and blood products is essential during resuscitation and/or hemorrhage. There is increased use of needleless connectors to minimize catheter-related infections and blood exposure. In this study, we question the flow difference between rapidly administering crystalloid or blood products through these connectors.

Our findings demonstrate that when using a Level 1 rapid infusion system, omitting a needleless connector can increase flow rates for undiluted RBCs by a factor of 2.86. Furthermore, our study demonstrates that when the resistance of a system is increased the relative importance of viscosity is greater.

There are many factors that can contribute to increased resistance across a system in clinical practice including patient-specific blood composition, use of extension tubing, stopcocks, drip chambers, and fluid warmers [1, 6]. Resistance to flow can be determined by Poiseuille's Law: $\mathbf{X}=8 \quad n l p \mathbf{\mathbb { }} 4$ where $R=$ resistance, $n$ $=$ viscosity, $l=$ length, and $r$ = radius, and any of these variables may be modified to alter resistance. Blood, a non-Newtonian fluid, can be subject to sludging and Rouleaux formation at low flow rates [7]. Additionally, a decrease in temperature can produce a significant increase in blood viscosity [8].

In order to responsibly utilize blood, our team procured two units of expired RBC (102 and 60 days past labeled expiration). Expired blood products are subject to decreased RBC deformability and increased hemolysis. While decreased RBC deformability affects flow in vivo, further experimentation is needed to determine whether this would affect flow through a large-bore IV catheter. Increased hemolysis, can cause increased blood viscosity however, we did not measure hemolysis in our RBC units [9].

\section{Conclusions}

In conclusion, in clinical situations necessitating rapid transfusion of RBC units, needleless connectors should not be used. If needleless connectors are used, then hemodilution should be considered to decrease the time required to deliver an equivalent red cell mass.

\section{Additional Information \\ Disclosures}

Human subjects: All authors have confirmed that this study did not involve human participants or tissue. Animal subjects: All authors have confirmed that this study did not involve animal subjects or tissue. Conflicts of interest: In compliance with the ICMJE uniform disclosure form, all authors declare the following: Payment/services info: All authors have declared that no financial support was received from any organization for the submitted work. Financial relationships: All authors have declared that they have no financial relationships at present or within the previous three years with any organizations that might have an interest in the submitted work. Other relationships: All authors have declared that there are no other relationships or activities that could appear to have influenced the submitted work.

\section{Acknowledgements}

Department of Anesthesiology, Perioperative and Pain Medicine Stanford University School of Medicine 


\section{Cureus}

Stanford, CA 94305

\section{References}

1. Lehn RA, Gross JB, McIsaac JH, Gipson KE: Needleless connectors substantially reduce flow of crystalloid and red blood cells during rapid infusion. Anesth Analg. 2015, 120:801-804.

10.1213/ANE.0000000000000630

2. Russo PL, Harrington GA, Spelman DW: Needleless intravenous systems: a review. Am J Infect Control. 1999, 27:431-434. 10.1016/s0196-6553(99)70009-X

3. Barton A, Ventura R, Vavrik B: Peripheral intravenous cannulation: protecting patients and nurses. Br J Nurs. 2017, 26:S28-S33. 10.12968/bjon.2017.26.8.S28

4. Btaiche IF, Kovacevich DS, Khalidi N, Papke LF: The effects of needleless connectors on catheter-related bloodstream infections. Am J Infect Control. 2011, 39:277-283.

5. Caballero JA, Rivera F, Edwards J, Brock-Utne JG: Pressure-rated needleless access connectors slow IV flow rate. Anesth Analg. 2010, 111:1077-1078. 10.1213/ANE.0b013e3181f0948c

6. Berman DI, Schiavi A, Frank SM: Factors that influence flow through intravascular catheters: the clinical relevance of Poiseuille's law. Transfusion. 2020, 60:1410-1417. 10.1111/trf.15898

7. Barshtein G, Wajnblum D, Yedgar S: Kinetics of linear rouleaux formation studied by visual monitoring of red cell dynamic organization. Biophys J. 2000, 78:2470-2474. 10.1016/S0006-3495(00)76791-9

8. Cinar Y, Mete Senyol A, Duman K: Blood viscosity and blood pressure: role of temperature and hyperglycemia. Am J Hypertension. 2001, 14:433-438. 10.1016/s0895-7061(00)01260-7

9. Yoshida T, Prudent M, D’Alessandro A: Red blood cell storage lesion: causes and potential clinical consequences. Blood Transfus. 2019, 17:27-52. 10.2450/2019.0217-18 